\title{
Quality Cost and Its Relationship to Revenue Sharing in Supply Chain
}

\author{
Fayza M. Obied-Allah ${ }^{1}$ \\ ${ }^{1}$ Associate Professor of Accounting, Accounting Department, Faculty of Commerce, Damanhour University, Egypt \\ Correspondence: Fayza M. Obied-Allah, Associate Professor of Accounting, Accounting Department, Faculty of \\ Commerce, Damanhour University, Egypt
}

Received: May 19, 2016

Accepted: June 10, 2016

Online Published: August 10, 2016

doi:10.5430/afr.v5n3p173

URL: http://dx.doi.org/10.5430/afr.v5n3p173

\begin{abstract}
Quality cost is one of the best ways to determine clearly the costs and returns of quality improvement efforts. This paper discusses the impact of the quality cost on revenue sharing as a most important incentive to configure business networks.

This paper develops the quality cost approach to measure quality costs which might enable firms to manage revenue sharing in a supply chain. The developed model includes five categories; besides the well-known four categories (namely prevention, appraisal, internal failure, and external failure costs), a new category has been developed in this study as a new vision of the relationship between quality costs and innovations in industry. This new category is herein after referred to Recycle Cost. This research also examines whether such quality costs in supply chains influence the revenue sharing between partners.

Using the author's quality cost model, the relationship between quality costs and revenue sharing among partners is examined using a case study in a company which is a part of a supply chain. This paper argues that the revenue-sharing proportion allocated to supplier increases as the recycle cost of supplier increases, and the revenue-sharing proportion allocated to manufacturer increases as the prevention and appraisal costs increase. The revenue-sharing proportion allocated to manufacturer increases as the failure costs, the recycle costs of manufacturer, and the recycle costs of suppliers decrease. However, the results present surprising findings.

The present study contributes to theory and practice by explaining how the cost of recycling can be combined in quality cost model to better understanding the revenue sharing among partners in supply chains.
\end{abstract}

Keywords: Case study, Quality cost, Recycle cost, Revenue sharing, Supply chain

\section{Introduction}

Quality improvements, value creation, meeting customer' needs and reducing costs through supply chain management provides challenges and opportunities for companies as well as researchers. New ideas must contribute to counter these challenges and exploit opportunities. In this respect, supply chain management presents new business opportunities.

There is a growing recognition that supply chain management offers significant opportunities for firms to enhance financial performance, create strategic advantage, and achieve mutually beneficial performance outcomes [Schloetzer, 2012]. No doubt, the costs directly have an influence on size of income generated by a business network. Recently, considerable attention has been devoted to investigate quality cost in supply chains. Although external failure cost is the most commonly used measure of quality [Balachandran \& Radhakrishnan, 2005; Chao et al, 2009], it is not a sufficient measure for the total cost of quality across the entire supply chain [Baiman et al, 2000]. Some studies, e.g. Ramudhin et al. (2008), focused on total quality cost at suppliers and suggested adding the quality cost of manufacturers (plants) in their model for further research. On the other hand, some studies investigated the revenue sharing in supply chain management, for example, Govindan \& Popiuc (2014) shows that significant returns are realized for all supply chain partners in revenue sharing cases, and the performance improves through coordination with revenue sharing contracts. Arya \& Mittendorf (2011) developed a model measuring segment profitability and coordinating self-interested supply chain partners. They found that the firm, within a supply chain, sometimes benefits from devoting resources to less profitable segments and perhaps even from serving seemingly unprofitable markets or customers. 
This study presents an advanced theoretical model for quality cost that enhanced models of quality cost presented in the literature. Recycle cost is a new category added to quality cost approach in this paper. Recycle cost is introduced in this paper due to the expectations for next period to have new systems to products reused, remanufactured, recycled and redesigned.

The motivation to this study is the forecast for the next era. Some experts predict that manufacturing in 2050 will look very different from today; a new vision for manufacturing will appear. Constant adaptability will pervade all aspects of manufacturing in supply chain, from research and development to creativity and innovation, production processes, supplier and customer relationships, and lifetime product maintenance and repair. Products and processes will be sustainable, with built-in reuse, remanufacturing and recycling for products reaching the end of their useful lives. Closed loop systems will be used to eliminate waste and to recycle physical waste. These developments will further emphasize the essential role of physical production in opening innovative new revenue streams [GOV.UK, 2013]. Therefore, the purposes of this study are developing a model to measure quality costs, which has five categories; prevention cost, appraisal cost, internal failure cost, external failure cost, and recycle cost. It then examines whether such quality costs in a supply chain influence the revenue sharing among partners.

The present study focuses on quality costs in supply chain and reflects quality cost elements relating to the manufacturers and suppliers. Further, it examines the impact of such quality costs on revenue sharing in a supply chain. To examine this issue, this study uses detailed quality cost data collected from a car filters manufacturer regarding its contractual arrangements with its suppliers. Due to data limitations, some studies use surveys that explain observed behavior in the expected relationship. This study conducts a more powerful test of the relationship between quality costs and revenue sharing by using data from individual partner. This study provides a more direct examination of whether quality cost affects the percentage of total revenue each partner in a supply chain.

This study contributes in the literature to develop quality cost model in the companies are interested in introducing green product (i.e. environmentally friendly product) which can be recycled. Therefore, the present study contributes to theory and practice by presenting an advanced theoretical model for quality cost that enhanced models of quality cost presented in the literature and explaining how the cost of recycling can be combined in quality cost model to better understanding the relationships between quality costs and revenue sharing in supply chains.

This paper is organized as follows: Section 2 presents the related literature review. Section 3 discusses the theoretical development of this study. In this section, the quality cost approach is developed and the impact of quality cost on revenue sharing in supply chain is investigated. Section 4 includes a research method which conducts a case study and presents the statistical results. Section 5 discusses the results and shows future opportunities for research. Finally, Section 6 summarizes the theoretical and practical results of this study.

\section{Literature Review}

The importance of supply chain management, and incorporating it into strategic cost management, has increased over time to achieve the strategic goals of improving product quality, improving organization's operational and financial performance, reducing costs, increasing customer value and satisfaction, and maintaining competitive advantages [Vann, 2016]. However, in management accounting literature, there is no research, to the best of the author's knowledge, investigates the relationship between quality costs and revenue sharing in supply chains. Therefore, the relevant literature is examined as follows:

\subsection{Quality Cost in Supply Chain}

Supply chain relationships can be easier when Accounting provides advanced information about Quality Costs [Burritt \& Schaltegger, 2014]. Many firms are now increasingly adopting inter-firm contractual arrangements to achieve competitive advantage. Firms gain many benefits from such arrangements because of the changing of relationships from short-term to long-term, such benefits as increasing market share, cost reduction, improve performance, as well as gain more skills and knowledge [Dacin et al., 2007; Fayard et al., 2012; Ireland et al., 2002; Mamat, 2012; Langfield-Smith \& smith, 2005].

Supply chain linkages are critical to quality, on-time delivery, and cost reduction. From the supply chain viewpoint, provision of high quality products at low cost helps firms satisfy more customers and raise supply chain profits. Although quality cost has been applied within a large number of companies as an in- house measurement, it is crucial to extend quality cost as an external measure and integrate traditional manufacturing costs and distribution costs into supply chain modeling [Castillo-Villar et al., 2012a; Srivastava, 2008]. 
Quality cost across a supply chain is the sum of the costs incurred across a supply chain in preventing poor quality of product and/or service to deliver to final consumer, the costs incurred to ensure and evaluate that the quality requirements are being met, and any other costs incurred as a result of poor quality [Srivastava, 2008].

Some studies investigated the relation between quality cost and supply chain management, such as Srivastava (2008) which gave the first step towards estimating quality cost in a supply chain. They estimated quality costs in monetary terms according to P-A-F model and used standard DMAIC (Define-Measure-Analyze-Improve-Control) methodology for analysis at selected third-party contract manufacturing sites of a pharmaceutical company. Ramudhin et al. (2008) also focused on integration of quality cost in the supply chain. Their study presented a mathematical model for a single product, three-echelon system (i.e. suppliers, plants, and customer groups) that aimed at minimizing the overall operational and quality costs (i.e. total cost of production at the supplier, total cost of transportation from suppliers to plants, quality cost at the supplier, total production cost at the plant, total cost of transportation from plants to customers). Ramudhin et al. (2008) focused on total quality cost at suppliers when making a decision of supplier selection. By removing the quality cost terms from the model, a difference of approximately 16 percent in the value of the objective function was obtained. When quality cost is not included, supplier that is running at a high quality failure cost is treated similarly to the one that is operating at a lower quality failure cost, given they both have the same production cost. Therefore, the final optimal network will choose key suppliers who have the lowest operational costs, without considering the quality failure cost from the defective components received from the suppliers. Thus, choices made solely on production cost may sacrifice quality and lead to additional quality failure costs or corrective action costs in the next stages of the supply chain. Fayard et al. (2012) contributed to understand of the ability to manage inter-organizational quality cost that gives organizations an advantage over their competition. Moreover, Castillo-Villar et al. (2012a) aimed to develop a strategic-level model for computing the quality cost in a formulation of a single-product, multi-stage, serial supply-chain network design (SCND) problem. Their study was dealing with the development of an SCND model that calculated the quality cost for a whole supply chain based on internal decisions within the manufacturing plants, such as fraction defective at the plant and error rate at inspection points. No earlier work has addressed how the quality cost curves are obtained by taking internal and operational decisions within the supply chain; in earlier studies, the total quality cost function based on percentage of defective units is assumed to be given. Castillo-Villar et al. (2012a) presented a model for supply chain design that considers the quality cost as well as the traditional manufacturing and distribution costs. The results show that quality cost function, although nonlinear, could be integrated into supply chain modeling and solved efficiently. More recently, Castillo-Villar et al. (2012b) presented a methodology to compute the cost incurred by various partners within the supply chain due to the quality cost. A supply chain was consisting of three tiers, namely suppliers, manufacturers, and retailers. The proportion of good products among all products delivered to final customers is used as an overall parameter of quality level and assumed to be sufficient to represent quality. The proposed model seeks to benefit from prevention activities and make use of appraisal activities only when necessary or when the costs of prevention activities exceed appraisal costs by a great amount. A positive relationship between appraisal and internal failure costs emerged in the proposed model.

In summary, computing quality cost for a supply chain is the first step in integrating it into the decision process because it allows exploring the interrelationships among partners [Castillo-Villar et al., 2012b]. When quality cost is incorporated in a supply chain the overall operation costs will decrease [Ramudhin et al., 2008]; thereby the overall revenue will increase. Considering a supply chain with a manufacturer and a supplier, the manufacturer designs a product and owns the brand name, while the suppliers produce the components for the manufacturer. The production process at the supplier can yield nonconforming units, which incur some quality costs that are shared by both partners. Therefore, both partners have the incentive to improve quality [Zhu et al., 2007], and share quality cost.

Recently, considerable attention has been devoted to quality cost in supply chain management. It is becoming a common practice among manufacturers to present suppliers with quality cost sharing agreements to ensure accountability of quality problems and to create incentives for process improvement [Balachandran \& Radhakrishnan, 2005; Srivastava, 2008].

\subsection{Quality Cost Sharing in Supply Chain}

Many studies investigated quality cost sharing between partners in supply chain. For example, Balachandran \& Radhakrishnan (2005) modeled the fixed share rate contract for allocating the costs of internal failures, whereas Chao et al. (2009) considered a more general contracting arrangement for external failures. Chao et al. (2009) discussed designing cost sharing contracts that maximize the manufacturer's expected profit in a decentralized supply chain. They focused on sharing external quality costs of product recalls. They found that the optimal contract 
for the manufacturer was also the contract that coordinated the effort decisions of the manufacturer and the supplier and attained the first best profits and quality. Lim (2001) also assumed that the internal (rework) and external (warranty) quality costs were shared among the partners at a fixed rate. Baiman et al. (2000) analyzed the relationship in supply chains among product quality, cost of quality, and the information that could be contracted upon. In a risk neutral setting, the supplier incurred prevention costs to reduce the probability of selling a defective product, and the manufacturer incurred appraisal costs to inspect quality of the incoming part and discover defects. They assumed that the external quality costs are shared at a fixed rate. Otherwise, Zhu et al. (2007) stated that if the manufacturer's share of the quality cost is relatively high, he may instead prefer a high-quality supplier even if this requires him to take over the quality improvement effort. They found that quality costs associated with each nonconforming unit, which may include the cost of customer goodwill loss, shipping and handling costs, and material and labor costs. The supplier who was responsible for the manufacturing of the product often bears most of the warranty costs. The manufacturer as the brand owner suffered due to the damage to his reputation and future market share for each nonconforming unit sold in the market. Thus, there may be some room for the partners to negotiate their shares of the quality costs.

In brief, few studies have been examined quality cost sharing among partners in a supply chain; most of them depend on a fixed rate of sharing. Moreover, no research examines the relationship between quality cost and revenue sharing in supply chains. Therefore, this study discusses this issue by developing the quality cost approach and then examines its relationship with revenue sharing.

\section{Theoretical Development}

\subsection{Developing the Quality Cost Approach}

Quality Cost is a powerful measurement system that translates the activities of a quality programme and quality improvement efforts into a monetary language that management and every stakeholder can understand and act upon. Quality cost concepts affect operating costs, profitability, and customer need [Castillo-Villar et al., 2012a; Srivastava, 2008]. Many earlier studies investigated quality cost. They discussed the definition and classification of quality costs into categories. Some of them developed quality cost categories into models; each model had its features. Also, some studies investigated quality cost models, and classified them in groups. For example, Omar \& Murgan (2014) and Schiffauerova \& Thomson (2006) classified quality cost models into five groups; these were: (1) P-A-F (prevention, appraisal, and failure) model. (2) Crosby's model which includes conformance and non-conformance cost. Some studies, e.g. Schiffauerova \& Thomson (2006) classified P-A-F model and Crosby's model in one group because they describe the same categories. (3) Opportunity cost models which includes opportunity cost plus P-A-F, conformance and non-conformance cost, or intangibles (4) Process cost models, and (5) ABC (activity based costing) models which include value-added and non-value-added.

Castillo-Villar et al. (2012b) shed light on six theories of quality cost models. These are: Juran's model, Lesser's contribution, P-A-F model, the economics of quality, business management and the cost of quality, and Juran's revised model.

In spite of the multiplicity of quality cost models, the most applied models in practice are P-A-F model, and the original model of Juran that is known as the traditional cost of quality trade-off between prevention and appraisal costs on the one hand and failure costs on the other. The original model of Juran still provides a frame of reference for quality costs and quality improvement, although it is not very adequate for current manufacturing processes. Each company can edit its model for quality cost according to its needs because what is important in a company may not be important in another company. These differences among companies are resulting in the various quality cost structures. Therefore, there is not one basis can be used in comparing the results of different companies. However, the principles of the P-A-F model remain generally unchanged throughout the researched companies [Castillo-Villar et al., 2012a; Schiffauerova \& Thomson, 2006].

Generally, most studies agree on the four categories of the quality costs, namely: (1) Prevention costs; are the cost of activities designed specifically to prevent poor quality. (2) Appraisal costs are the costs associated with evaluating and inspecting products to ensure conformance to quality standards. (3) Internal failure costs are the costs resulting from products not conforming to requirements that occur before the shipment to final customer, such as costs of scrap, reworking, retesting, re-inspection, or redesign. (4) The external failure costs are the costs resulting from products not conforming to requirements that occur after shipment to the final customer, which may indicate the cost of claims against warranty, replacement, and consequential losses, and evaluation of the penalties incurred [Abdelsalam \& Gad, 2009; Castillo-Villar et al., 2012a; Srivastava, 2008]. However, the newly inventions in the industrial age imposes many developments on management accounting. Products and processes will be sustainable. 
Products are reaching the end of their useful lives will reuse, remanufacture, and recycle. Therefore, products that can be reused either for the same purpose or for other purposes and the pressures to produce environmentally friendly products (Green products) that can be recycled are great motivations to develop quality cost approach in this paper.

Recycle Cost is a new category has been developed in this research as a new vision of the relationship between quality costs and innovations in industries. Recycling is the process of manufacturing new products from a product that has originally served its purpose. Recycling is intended to rotate the product that can extract the valuable materials and then use them to produce new products. If these used products are disposed in an appropriate environmentally friendly way, the process of recycling has been set in motion. The design of green products has increasingly importance in managing the sustainability performance of supply chains. Therefore, recycling process in a supply chain is saving money while helping the environment. Products that are not recycled at the end of their life increasingly damage the environment, but re-manufacturing products at the end of their life can generate new profits [Chan et al., 2014; Govindan \& Popiuc, 2014].

The recycling process begins at the suppliers by collection process. Waste management systems are classified into systems with recycling and systems without recycling. Systems with recycling can be distinguished by their predominated collection system [Beigl \& Salhofer, 2004]. Govindan \& Popiuc (2014) defined four recycling channels for Personal Computers; these are: (1) Resale; Products that are no longer useful for the customer can be offered for resale in the secondhand market, (2) Exchange; some of the original manufacturers provide an opportunity for exchange. They collect old products when a customer purchases a new product, (3) Take back; other manufacturers offer a coupon for further purchases or free services in exchange for a used product, and (4) Scraping; if the products are of no further use, they are separated into component parts and recycled to enter new production systems.

Some studies referred to the cost of recycling as the collection costs, e.g. Tonjes \& Mallikarjun (2013) who carried out cost effectiveness analysis of seven different scenarios of refuse a collection in New York. Other studies investigated the costs of different collection schemes of waste such as Beigl \& Salhofer (2004), Groot et al (2014) and Larsen et al. (2010); they compared all relevant costs of the different options in collection and concluded the difference in cost between the methods is relatively small.

The cost of collection includes vehicle cost (which is split into fixed and variable cost), labour cost, tools, container cost and cost of other direct and indirect expenses to collect used products from source (customers) [Debnath \& Bose, 2014; Groot et al., 2014]. In addition to the operational cost of collection and sorting, Cruz et al. (2012) added depreciation of assets and return on capital costs to compare system benefits. The study found that the net economic sustainability of the recycling of packaging waste is largely dependent on the type of packaging material recycled.

Similar to Tonjes \& Mallikarjun (2013), the study considers the collection costs at supplier as the cost of recycling. Consequently, the recycle cost at supplier is estimated as a sum of direct and indirect costs of collection process.

In addition to the recycle cost at supplier, the cost of recycling process at the manufacturer contains three groups; (1) Purchasing cost which includes the price paid to the used products' supplier, transport cost and commission, etc. (2) Quality cost of recycling which is referred in this study recycle cost at manufacturer. It includes sorting cost, inspection cost, refurbishing cost and waste disposal cost that incurred to throw useless components. The recycled product must be refurbished to certain quality standard. The core processes consist mainly of disassembly, cleaning, inspection, refurbishment, re-assembly and testing for quality control, etc. (3) Remanufacturing cost which includes variable costs and overhead manufacturing costs. Remanufacturing cost may be visible cost when the used components are manufactured in a separate production line. It could also be invisible, or hidden, cost when the used and new components are added to the production line at the same time. Obviously, without quantifying the cost of recycling, the remanufacturing costs would have been considered a normal production cost. This classification depends on the type of material recycled (e.g. paper, glass, plastics, metals, mobile phone, computers, heavy machines, etc.) and the production method.

Some studies investigated the cost of recycling according to the type of material recycled, e.g. Chao \& Liao (2011) aimed to minimize the total cost, including the total holding cost of keeping the recycled glass and loss cost due to the low valued glass in the manufacturing of a glass recycling factory in Taiwan. Groot et al. (2014) developed a comprehensive cost model to compare costs of various collection schemes of plastic packaging waste (their study focuses on two collection schemes), and concluded the difference in cost between the two methods is not significant in general. Parthasarathy (2001) determined the global cheapest mixing and recycling scheme for a given chemical process using non-linear program formulation. Moreover, some studies investigated the cost of recycling and 
remanufacturing process, such as Lakhan (2015) examined the impact of "non-core" material recycling on system costs and diversion levels (where non-core materials are defined as materials with high material management costs and low levels of recyclability). The results show that removing non-core materials from the residential recycling program significantly decreased system costs without negatively impacting overall recycling rates. Larsen et al. (2010) found that the costs of collection and treatment of waste were reduced with increasing recycling. Henri et al. (2015) argued that using the recycled components would reduce the cost of direct and indirect materials.

Debnath \& Bose (2014) investigated full cost accounting framework to examine its ability in evaluating cost of the municipal solid waste services. They also expanded it by integrating externalities (i.e. environmental and social costs), to generate information on cost related aspects and sustainable deployment of resources and explore the capabilities in supporting improved decision making.

One important finding is excluded from the prior studies is that no study combines recycle cost with quality cost at manufacturer. Therefore, this study suggests that the recycle cost is a part of quality cost. Consequently, total quality cost at manufacturer is the sum of quality costs not related to recycling, i.e. prevention, appraisal, internal failure, and external failure costs, and quality cost related to recycling, i.e. recycle cost.

Considering a supply chain with one manufacturer and many suppliers, the total cost of quality in this supply chain is the sum of recycle cost at supplier and total quality cost at manufacturer. The Prevention-Appraisal-Failure-Recycle (PAFR) model is used to estimate quality costs in monetary terms.

Both manufacturer and supplier can exert effort to reduce quality cost and increase revenue sharing, hence making the overall supply chain more efficient. Therefore, this study measures quality cost at manufacturers and suppliers which may enable firms to manage revenue sharing in a supply chain.

\subsection{The Impact of Quality Cost on Revenue Sharing in Supply Chain}

Revenue sharing is a growing field of interest for many researchers and practitioners since the last decade. Revenue sharing is an effective mechanism for coordinating decisions in a supply chain. In supply chains, each partner seeks to maximize her/his own benefits. Therefore, incentives are a key mechanism to improve supply chain performance by aligning interests and decisions of all supply chain partners. Incentives lead to higher benefits for the entire supply chain. These incentives are imposed by the implementation of coordination contracts to improve supply chain efficiency, reduce the adverse impact of the double marginalization and improve firm social responsibility. A variety of contracts have been designed in the past few decades, such as revenue sharing, wholesale price, buy back, quantity flexibility, sales rebate, and quantity discount, among which the revenue sharing contract is the most widely used scheme in improving supply chain performance [Govindan \& Popiuc, 2014; Henry \& Wernz, 2015; Zhang et al., 2015].

Revenue sharing contracts play an important role in the management of supply chains and coordinate supply chain decisions [Krishnan \& Winter, 2011; Wang \& Shin, 2015]. In the literature, it was observed that a revenue sharing contract performs very well in terms of profit improvement under coordination and brings the highest benefit to the manufacturers [Govindan \& Popiuc, 2014]. Revenue sharing contracts enhance supply chain coordination and increase market share, for example using revenue sharing contracts in Blockbuster Inc. increased its market share from $24 \%$ in 1997 to $40 \%$ in 2002 [Palsule-Desai, 2013]. Revenue sharing can work as an incentive mechanism in the agency problem across partners [Atkinson et al., 1988].

Corbett \& DeCroix (2001) discussed the use of a shared savings contract (assuming a fixed share rate between a supplier and a manufacturer) that reduces indirect material consumption. However, they found that the goals of maximizing joint profits and minimizing consumption were generally not aligned. Surprisingly, a decrease in a cost parameter could lead to a decrease in total profits; it may be necessary to renegotiate the shared-savings contract to reap the benefits of a cost decrease.

Palsule-Desai (2013) investigated the benefits of enhanced coordination by adopting revenue-dependent contracts as against revenue-independent contracts. The result indicated that supply chains could be perfectly coordinated using revenue sharing contracts. However, revenue-dependent revenue sharing contracts did not influence the supply chain profit function; but they affected the revenue sharing proportion. In this scene, this study takes into consideration the revenue sharing proportion and examines how extent it is affected by the quality costs at manufacturer and supplier.

Govindan \& Popiuc (2014) defined an analytical model to explore the implications of recycling on the reverse supply chain from an efficiency perspective for all participants in the process. The attention in Govindan \& Popiuc (2014) was directed on the take back channel under the assumption that for each recycled personal computer with remanufacturing value, the company offers the final customer a discount for a new purchase in the form of coupon to 
be used with his/her retailers. Their study show that performance improves and significant returns were realized for all supply chain partners in revenue sharing cases.

Like studies that assumed that quality costs are shared among partners in supply chain at a fixed rate (e.g. Baiman et al., 2000; Balachandran \& Radhakrishnan, 2005; Corbett \& DeCroix, 2001; Lim, 2001), some studies also assumed that the revenues are shared at a fixed rate, this assumption is widely adopted in the movie and video rental industry. For instance, Rentrak, a distributor in the video rental industry, offers $45 \%$ of the revenue from a movie to the studio, $45 \%$ to a retailer, and retains the remaining $10 \%$ of the revenue [Palsule-Desai, 2013]. Other studies stated that with revenue sharing contracts in supply chain there are two approaches; these are: (1) The spanning revenue sharing contract, where one partner takes the lead in forming contracts with each other partners in the supply chain. Therefore, each partner of the supply chain takes a fraction of the revenue realized by the leader. Supply chain is consisting of three partners, namely suppliers, manufacturers, and customers (and/or retailers). Under the revenue sharing contract, revenue generated by the manufacturer is to be shared among supply chain partners; and (2) The pair-wise revenue sharing contract, where contracts between all pairs of adjacent entities are installed to allocate a fraction of the revenue generated by each other [Govindan \& Popiuc, 2014; Van der Rhee et al., 2010].

The roles of different partners in a supply chain in quality improvement were explored by some researchers, e.g. Zhu et al. (2007) which show that the manufacturer's involvement can have a significant impact on the profits of both partners and of the supply chain as a whole. The manufacturer can convey the opportunity cost of external failure to the supplier by imposing penalties on the supplier's poor quality [Balachandran \& Radhakrishnan, 2005]. As well, the manufacturer often takes the first step and designs the revenue sharing contract. When designing the contract, the manufacturer provides sufficient incentives for the suppliers so that the supplier accepts the contract. The incentive provided to the supplier to have her/his accept a contract is an increase in the revenue sharing proportion paid by the manufacturer to the supplier [Chao et al., 2009]. Therefore, each partner in supply chain tries to maximize his own revenue and chooses the percentage of the revenue sharing accordingly. To investigate the impact of quality cost on the percentage of revenue sharing each partner in a supply chain, this study suggests the following: (1) The revenue-sharing proportion allocated to supplier increases as the recycle cost of supplier increases, (2) The revenue-sharing proportion allocated to manufacturer increases as the prevention and appraisal costs increase, as well as the failure costs, the recycle costs of manufacturer, and the recycle costs of suppliers decrease.

\section{Research Method}

\subsection{Explanatory Case Study}

A single case study can investigate a contemporary phenomenon within its real life context, and provide multiple data sources [Yin, 1994]. The provided data have an emphasis on depth and quality, rather than population size [Eisenhardt, 1989]. Thus, this study conducts a case study to investigate the relationships between the quality cots and revenue sharing.

\subsection{Data Sources}

Data are collected using multiple sources. Internal reports of quality cost, the purchase statements, financial annual reports, manager observation in meetings, and the company website are the primary sources of data.

\subsection{Case Study}

A case study is performed of an Egyptian manufacturing company of Filters. It was established in 1958. It is specialized in manufacturing automotive and industrial filters such as fuel, gasoline, oil, air, panel, gas turbine, and other special filters, covering more than 1,500 types of filters, with a maximum capacity of 8,000,000 units per year.

Raw materials and components are purchased from the best international suppliers that ensuring the ultimate filtration, meeting safety requirements, and making robust, reliable, durable, and resilient filter. Currently, the company has six international suppliers, 17 local suppliers, and many dealers (its dealers are service-centers related to 28 big automotive manufacturing companies).

The case study's vision is to become a competitive company by applying new technology and innovation, improve quality and meet customer needs and expectations. It has three production lines; Spin on filters line production for producing durable spin on oil and fuel filters with high technology deep drawing, forming special steel, and very efficient pleated paper, Cartridge filters line production for producing oil and fuel filters with highly efficiently pleated paper, and high technology assembly system. This production line can produce cartridge element for oil and fuel applications, and Air filters line production for producing all air filter types; heavy-duty, panel and radial sealing. 
In the case study, quality starts by accurately using selected raw materials and components, passing through multilayer audits and inspection procedures, including all production processes. These processes ensure the quality of all materials and components used in producing the filters. Fig. 1 illustrates the product life cycle in the case study, which starts with raw material extraction from disassembled parts and new material and components, and goes through component production, assembly, quality control and finishing, and marketing and distribution to customers for usage and disposal at product end-of-life. The supplier then purchases the disposal products from customers and sorting them to sell to the manufacturer.

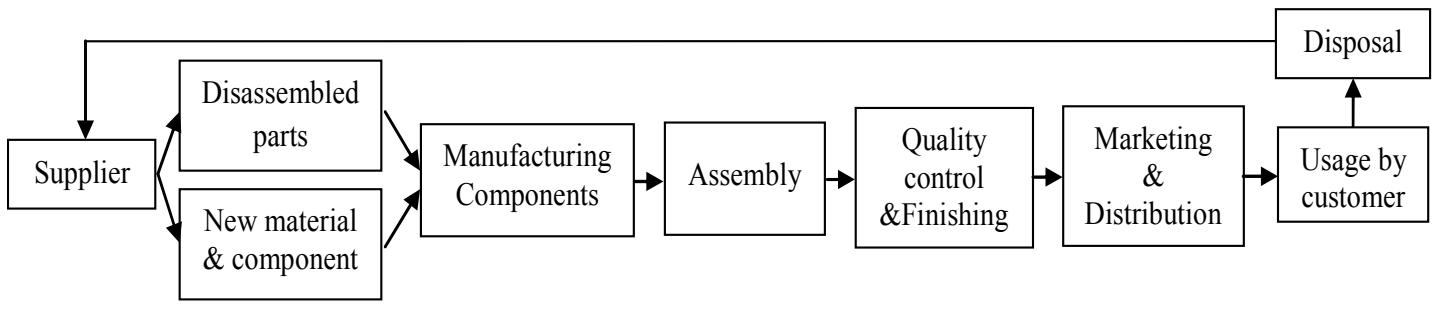

Figure 1. Product life cycle in the case study

The quality cost model (P-A-F-R) is estimated in the case study for the year 2011-2014 at the filters' company, which prevention costs have many components: industrial security, training, insurance, wages and salaries of quality assurance, maintenance of inspection machines, quality engineering, and planning, and engineering design.

The company considers sorting and inspection costs as prevention costs, but we deduct them from the prevention costs and add them to recycle cost of manufacturer. Appraisal costs have the following components: wage of inspectors, depreciation of laboratory machines, materials used in inspection, and other appraisal costs. Internal failure cost includes scrap, waste in material, rework, and repackaging. External failure cost includes sales returns, delay penalties, costs of studying customer complaints, compensations, and claims expenses.

As mentioned before, Govindan \& Popiuc (2014) referred to four kinds of recycling product in supply chain; resale, exchange, take back, and scraping. In this case study, one kind of recycling is found, where the recycling product is dependent on separation the old product into component parts and recycled to enter new production systems (scraping). The company also purchases old components from component providers and recycled them. Therefore, the recycle cost at manufacturer includes sorting, inspection, and refurbishing costs. Currently, the company considers the refurbishing costs as a part of production cost. We determine these remanufacturing costs to be a part of recycle cost at manufacturer. The recycle cost at supplier includes disassembled parts cost. It is calculated through deducting the percentage of contribution margin in this industry $(20 \%)$ from the purchase costs that appear in the accounting books of manufacturer. The result is the cost of disassembled parts that assumed in this study to be equal collection cost, i.e. recycle cost at supplier. On the other hand, the percentage of revenue sharing for each partner is calculated by dividing her/his revenue over the total revenue of manufacturer plus the revenue of suppliers that they obtain from the manufacturer.

4.4 The Results and Analysis

Table 1 shows the result of applying the quality cost model (P-A-F-R). The results appear the percentage of each category in quality costs in detail and in total. 
Table 1. Applying P-A-F-R Model

\begin{tabular}{|c|c|c|c|c|}
\hline Quality Cost & 2011 & 2012 & 2013 & 2014 \\
\hline \multicolumn{5}{|l|}{ Prevention costs: } \\
\hline Industrial security & $0.14 \%$ & $0.02 \%$ & $0.11 \%$ & $0.09 \%$ \\
\hline Training & $4.17 \%$ & $0.20 \%$ & $0.11 \%$ & $0.10 \%$ \\
\hline Insurance & 00 & $2.15 \%$ & $0.88 \%$ & $1.10 \%$ \\
\hline $\begin{array}{l}\text { Wages and salaries of quality } \\
\text { assurance }\end{array}$ & $1.07 \%$ & $1.20 \%$ & $1.20 \%$ & $1.21 \%$ \\
\hline Maintenance of inspection machines & $0.37 \%$ & $0.31 \%$ & $0.46 \%$ & $0.15 \%$ \\
\hline Quality engineering and planning & $2.16 \%$ & $2.36 \%$ & $3.11 \%$ & $2.78 \%$ \\
\hline Engineering design & $1.33 \%$ & $2.36 \%$ & $1.07 \%$ & $0.70 \%$ \\
\hline Total & $9.24 \%$ & $14.50 \%$ & $6.94 \%$ & $6.13 \%$ \\
\hline \multicolumn{5}{|l|}{ Appraisal costs: } \\
\hline Wage of inspectors & $1.66 \%$ & $3.17 \%$ & $3.45 \%$ & $3.77 \%$ \\
\hline Depreciation of laboratory machines & $3.60 \%$ & $3.00 \%$ & $2.79 \%$ & $2.87 \%$ \\
\hline Materials used in inspection & $0.05 \%$ & $0.06 \%$ & $0.05 \%$ & $0.03 \%$ \\
\hline Other & --- & $0.12 \%$ & $0.27 \%$ & $0.10 \%$ \\
\hline Total & $5.31 \%$ & $10.43 \%$ & $6.56 \%$ & $6.77 \%$ \\
\hline \multicolumn{5}{|l|}{ Internal failure cost: } \\
\hline Scrap & $1.98 \%$ & $1.28 \%$ & $1.12 \%$ & $1.45 \%$ \\
\hline Waste in material & $10.78 \%$ & $10.36 \%$ & $12.02 \%$ & $9.98 \%$ \\
\hline Rework & $0.02 \%$ & $0.04 \%$ & $0.09 \%$ & $0.48 \%$ \\
\hline Repackaging & --- & $0.03 \%$ & --- & --- \\
\hline Total & $12.78 \%$ & $19.26 \%$ & $13.22 \%$ & $11.91 \%$ \\
\hline \multicolumn{5}{|l|}{ External failure cost: } \\
\hline Returns & $24.48 \%$ & $32.74 \%$ & $23.01 \%$ & $28.73 \%$ \\
\hline Delay penalties & $1.66 \%$ & $1.14 \%$ & $0.33 \%$ & $4.57 \%$ \\
\hline $\begin{array}{l}\text { Costs of studying customer } \\
\text { complaints }\end{array}$ & $0.12 \%$ & $0.03 \%$ & $0.02 \%$ & $0.06 \%$ \\
\hline Compensations & & --- & --- & $0.89 \%$ \\
\hline Claims expenses & & --- & $1 \%$ & $0.60 \%$ \\
\hline Total & $26.26 \%$ & $55.81 \%$ & $23.97 \%$ & $34.85 \%$ \\
\hline \multicolumn{5}{|l|}{ Recycle cost at manufacturer: } \\
\hline Sorting & $0.84 \%$ & $0.14 \%$ & $0.24 \%$ & $0.08 \%$ \\
\hline Inspection & $2 \%$ & $2.81 \%$ & $1.68 \%$ & $1.32 \%$ \\
\hline Refurbishing & $6.77 \%$ & $18.08 \%$ & $6.86 \%$ & $5.64 \%$ \\
\hline Total & $9.41 \%$ & $21 \%$ & $9 \%$ & $7.04 \%$ \\
\hline \multicolumn{5}{|l|}{ Recycle cost at supplier: } \\
\hline Disassembled parts cost & $37 \%$ & $33 \%$ & $41 \%$ & $33 \%$ \\
\hline$\overline{\text { Total }}$ & $37 \%$ & $33 \%$ & $41 \%$ & $33 \%$ \\
\hline Total quality costs & $100 \%$ & $100 \%$ & $100 \%$ & $100 \%$ \\
\hline
\end{tabular}


Tables 2 and 3 show the ratio of quality costs to total production cost and the ratio of quality costs to sales revenue at manufacturer and supply chain respectively. Whereas several studies, e.g. Albright \& Roth (1992) and Srivastava (2008), indicated that quality cost may represent 30 percent of total manufacturing costs, this case study provides that quality costs (includes recycle cost in the supply chain) fall somewhere between five and six percent of total costs.

Albright \& Roth (1992) estimated that quality cost is between approximately $15 \%$ and $25 \%$ of total sales in any organization. Srivastava (2008) found that overall quality cost in a supply chain was approximately $1.25 \%$ of the sales revenue, and Zimwara et al. (2013) estimated the quality costs to be $6.6 \%$ of sales revenue, the findings in this study show that the quality cost in the supply chain is between four and five percent of total sales.

Table 2. The Ratio of Quality Costs at Manufacturer

\begin{tabular}{lllll}
\hline Ratio of quality costs & 2011 & 2012 & 2013 & 2014 \\
\hline Ratio of quality costs to total costs & $6.93 \%$ & $7.72 \%$ & $6.33 \%$ & $7.47 \%$ \\
Ratio of quality costs to sales revenue & $5.46 \%$ & $6.15 \%$ & $5.39 \%$ & $7 \%$
\end{tabular}

Table 3. The Ratio of Quality Costs at Supply Chain

\begin{tabular}{lllll}
\hline Ratio of quality costs & 2011 & 2012 & 2013 & 2014 \\
\hline Ratio of quality costs to total costs & $5.36 \%$ & $5.97 \%$ & $4.89 \%$ & $5.78 \%$ \\
Ratio of quality costs to sales revenue & $4.23 \%$ & $4.76 \%$ & $4.10 \%$ & $4.96 \%$
\end{tabular}

To examine the relationships among the quality cost categories, a Pearson correlation test is performed. As shown in Table 4, there is a strong statistically significant correlation between prevention cost and recycle cost at manufacturer (Correlation coefficient $=0.970, \mathrm{p}<0.05$ ). There is also a strong statistically significant correlation between internal failure cost and recycle cost at manufacturer (Correlation coefficient $=0.997, p<0.05$ ). Further, there are negative relationships between recycle cost at supplier and all other quality cost categories (Correlation coefficients are negatives, $\mathrm{p}>0.05$ ). Otherwise, the correlations are not statistically significant between other categories of quality costs. Likewise, Figs. 2 (a), (b) illustrate the relations among all categories of quality cost in the case study.

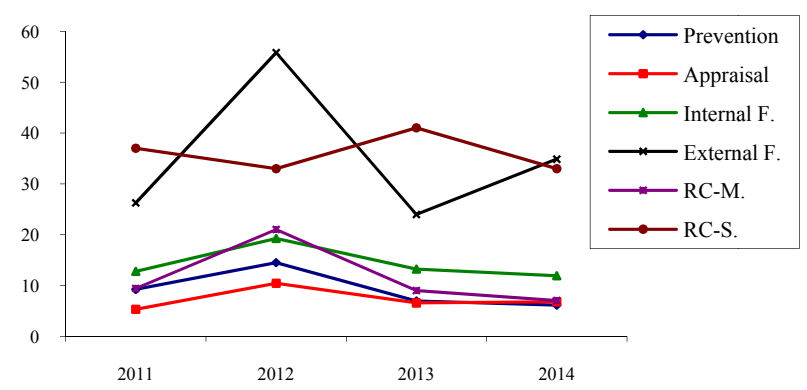

Figure 2 (a). the relations among quality cost categories

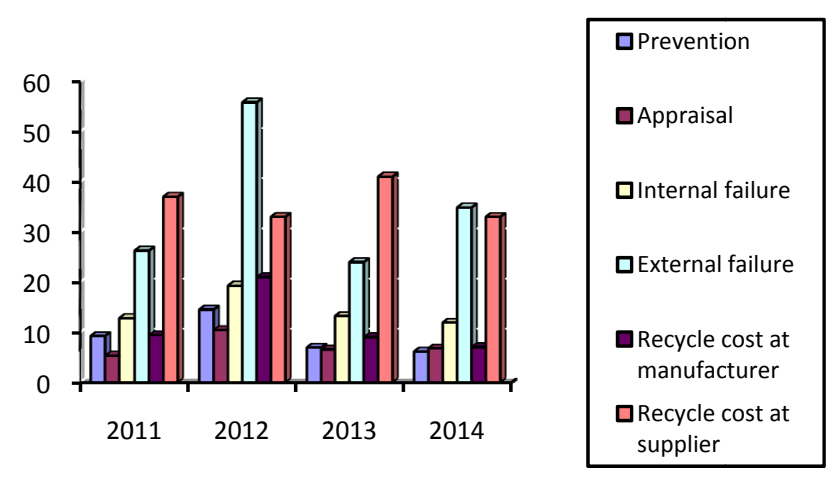

Figure 2 (b). the relations among quality cost categories during 2011-2014 
Table 4. Pearson Correlation among All Categories of Quality Costs and Percentage of Revenue Sharing

\begin{tabular}{|c|c|c|c|c|c|c|c|c|c|c|}
\hline & & $\begin{array}{l}\% \\
\text { Prevention }\end{array}$ & $\begin{array}{l}\% \\
\text { Appraisal }\end{array}$ & $\begin{array}{l}\text { \% } \\
\text { Internal } \\
\text { failure }\end{array}$ & $\begin{array}{l}\text { \% } \\
\text { External } \\
\text { failure }\end{array}$ & $\begin{array}{l}\text { \% } \\
\text { Recycle- } \\
\text { Manuf. }\end{array}$ & $\begin{array}{l}\text { \% } \\
\text { Recycle- } \\
\text { Suppl. }\end{array}$ & $\begin{array}{l}\text { \% } \\
\text { Internationa } \\
1 \text { Suppl. }\end{array}$ & $\begin{array}{l}\% \\
\text { Local } \\
\text { Suppl. }\end{array}$ & $\begin{array}{l}\% \\
\text { Manuf. } \\
\text { share }\end{array}$ \\
\hline \multirow[t]{2}{*}{$\%$ Prevention } & $\begin{array}{l}\text { Pearson } \\
\text { Correlation }\end{array}$ & 1 & .795 & .949 & .825 & $.970^{*}$ & -.414 & -.768 & -.752 & .762 \\
\hline & Sig. (2-tailed) & & .205 & .051 & .175 & .030 & .586 & .232 & .248 & .238 \\
\hline \multirow[t]{2}{*}{$\%$ Appraisal } & $\begin{array}{l}\text { Pearson } \\
\text { Correlation }\end{array}$ & .795 & 1 & .929 & .947 & .909 & -.533 & -.224 & -.198 & .214 \\
\hline & Sig. (2-tailed) & .205 & & .071 & .053 & .091 & .467 & .776 & .802 & .786 \\
\hline \multirow[t]{2}{*}{$\begin{array}{l}\% \text { Internal } \\
\text { failure }\end{array}$} & $\begin{array}{l}\text { Pearson } \\
\text { Correlation }\end{array}$ & .949 & .929 & 1 & .882 & $.997^{* *}$ & -.379 & -.556 & -.528 & .544 \\
\hline & Sig. (2-tailed) & .051 & .071 & & .118 & .003 & .621 & .444 & .472 & .456 \\
\hline \multirow[t]{2}{*}{$\begin{array}{l}\% \text { External } \\
\text { failure }\end{array}$} & $\begin{array}{l}\text { Pearson } \\
\text { Correlation }\end{array}$ & .825 & .947 & .882 & 1 & .885 & -.755 & -.306 & -.297 & .302 \\
\hline & Sig. (2-tailed) & .175 & .053 & .118 & & .115 & .245 & .694 & .703 & .698 \\
\hline $\begin{array}{l}\% \\
\text { Recycle-Manuf }\end{array}$ & $\begin{array}{l}\text { Pearson } \\
\text { Correlation }\end{array}$ & $.970^{*}$ & .909 & $.997^{* *}$ & .885 & 1 & -.408 & -.608 & -.583 & .598 \\
\hline$\cdot$ & Sig. (2-tailed) & .030 & .091 & .003 & .115 & & .592 & .392 & .417 & .402 \\
\hline \multirow[t]{2}{*}{$\begin{array}{l}\% \\
\text { Recycle-Suppl. }\end{array}$} & $\begin{array}{l}\text { Pearson } \\
\text { Correlation }\end{array}$ & -.414 & -.533 & -.379 & -.755 & -.408 & 1 & .039 & .068 & -.051 \\
\hline & Sig. (2-tailed) & .586 & .467 & .621 & .245 & .592 & & .961 & .932 & .949 \\
\hline \multirow[t]{2}{*}{$\begin{array}{l}\text { \% International } \\
\text { Suppl. }\end{array}$} & $\begin{array}{l}\text { Pearson } \\
\text { Correlation }\end{array}$ & -.768 & -.224 & -.556 & -.306 & -.608 & .039 & 1 & $.998^{* *}$ & $-1.000^{* *}$ \\
\hline & Sig. (2-tailed) & .232 & .776 & .444 & .694 & .392 & .961 & & .002 & .000 \\
\hline \multirow[t]{2}{*}{ \% Local Suppl. } & $\begin{array}{l}\text { Pearson } \\
\text { Correlation }\end{array}$ & -.752 & -.198 & -.528 & -.297 & -.583 & .068 & $.998^{* *}$ & 1 & $-.999^{* *}$ \\
\hline & Sig. (2-tailed) & .248 & .802 & .472 & .703 & .417 & .932 & .002 & & .001 \\
\hline \multirow[t]{2}{*}{$\%$ Manuf. share } & $\begin{array}{l}\text { Pearson } \\
\text { Correlation }\end{array}$ & .762 & .214 & .544 & .302 & .598 & -.051 & $-1.000^{* *}$ & $-.999^{* *}$ & 1 \\
\hline & Sig. (2-tailed) & .238 & .786 & .456 & .698 & .402 & .949 & .000 & .001 & \\
\hline
\end{tabular}

*. Correlation is significant at the 0.05 level (2-tailed).

**.Correlation is significant at the 0.01 level (2-tailed).

Schloetzer (2012) used the percentage of total revenue each partner to measure whether the potential for hold-up in supply chains influences the extent of process integration and information sharing between partners. Like Schloetzer (2012), the present study uses the percentage of total revenue each partner to measure the effect of quality costs on revenue sharing in supply chains. Table 5 shows the percentage of revenue sharing each partner. In the case study, there are three types of partners; international suppliers, local suppliers, and the manufacturer. Moreover, Table 6 shows the correlations among (prevention + appraisal cost), (internal + external failure costs), (recycle costs at manufacturer + recycle costs at suppliers), and the percentage of revenue sharing for international suppliers, local suppliers and manufacturer. 
Table 5. The Percentage of Revenue Sharing among Partners

\begin{tabular}{lllll}
\hline Partners & 2011 & 2012 & 2013 & 2014 \\
\hline International suppliers share & $13.20 \%$ & $13.33 \%$ & $14.02 \%$ & $14.34 \%$ \\
Local suppliers share & $9.20 \%$ & $9.28 \%$ & $9.76 \%$ & $9.99 \%$ \\
Share percentage of manufacturer & $77.60 \%$ & $77.39 \%$ & $76.22 \%$ & $75.67 \%$ \\
\hline
\end{tabular}

The results show that the correlation is not statistically significant between prevention and appraisal costs on one hand and failure costs on the other hand (Correlation coefficient $=0.946, \mathrm{p}>0.05$ ). As well, there is not a statistically significant correlation between prevention and appraisal costs on one hand and recycle costs at both manufacturer and supplier on the other hand (Correlation coefficient $=0.756, p>0.05$ ). Further, there is not a statistically significant correlation between failure costs on one hand and recycle costs on the other hand (Correlation coefficient $=0.537, \mathrm{p}>0.05$ ). The results also show a statistically significant correlation between the percentages of revenue sharing for international suppliers and local suppliers (Correlation coefficient $=0.998, p<0.05$ ). Otherwise, the correlations among quality cost categories (prevention \& appraisal, failure, and recycle costs) and the percentage of revenue sharing for both international and local suppliers are negatives and not statistically significant (all Correlation coefficients are negatives, $\mathrm{p}>0.05$ ). Furthermore, there is a weak positive correlation and not statistically significant between the percentage of revenue sharing for manufacturer and the quality cost categories. Finally, there are negative correlations and strong statistically significant between the percentage of revenue sharing for manufacturer and the percentage of revenue sharing for both international (Correlation coefficient $=-1.000, p<$ 0.05 ) and local suppliers (Correlation coefficient $=-0.999, \mathrm{p}<0.05$ ).

Fig. 3 illustrates the relations between quality cost categories each other.

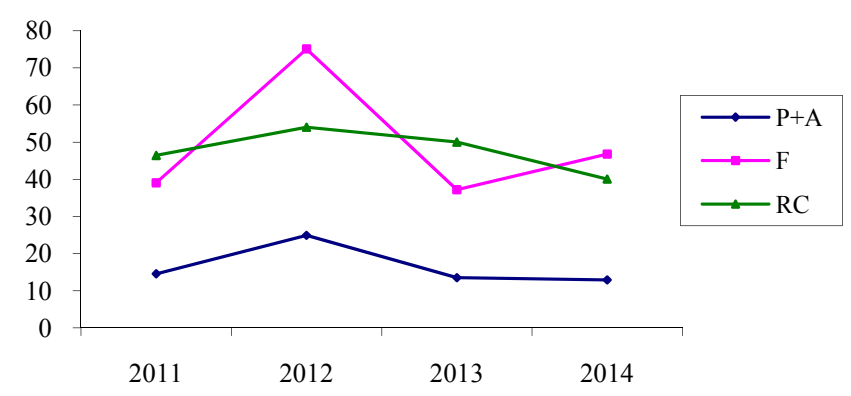

Figure 3 . The relations among quality cost categories 
Table 6. Pearson Correlation among Quality Cost Categories and the Percentage of Revenue Sharing for Each Partner

\begin{tabular}{|c|c|c|c|c|c|c|c|}
\hline & & $\% \mathrm{P}+\mathrm{A}$ & $\% \mathrm{~F}$ & $\% \mathrm{RC}$ & $\begin{array}{l}\text { \% International } \\
\text { Suppl. }\end{array}$ & $\begin{array}{l}\text { \% Local } \\
\text { Suppl. }\end{array}$ & $\begin{array}{l}\% \text { Manuf. } \\
\text { share }\end{array}$ \\
\hline \multirow[t]{2}{*}{$\% \mathrm{P}+\mathrm{A}$} & Pearson Correlation & 1 & .946 & .756 & -.596 & -.576 & .588 \\
\hline & Sig. (2-tailed) & & .054 & .244 & .404 & .424 & .412 \\
\hline \multirow[t]{2}{*}{$\% \mathrm{~F}$} & Pearson Correlation & .946 & 1 & .537 & -.359 & -.347 & .354 \\
\hline & Sig. (2-tailed) & .054 & & .463 & .641 & .653 & .646 \\
\hline \multirow[t]{2}{*}{$\% \mathrm{RC}$} & Pearson Correlation & .756 & .537 & 1 & -.625 & -.581 & .607 \\
\hline & Sig. (2-tailed) & .244 & .463 & & .375 & .419 & .393 \\
\hline \multirow{2}{*}{$\begin{array}{l}\text { \% International } \\
\text { Suppl. }\end{array}$} & Pearson Correlation & -.596 & -.359 & -.625 & 1 & $.998^{* *}$ & $-1.000^{* *}$ \\
\hline & Sig. (2-tailed) & .404 & .641 & .375 & & .002 & .000 \\
\hline \multirow[t]{2}{*}{ \% Local Suppl. } & Pearson Correlation & -.576 & -.347 & -.581 & $.998^{* *}$ & 1 & $-.999^{* *}$ \\
\hline & Sig. (2-tailed) & .424 & .653 & .419 & .002 & & .001 \\
\hline \multirow[t]{2}{*}{$\%$ Manuf. share } & Pearson Correlation & .588 & .354 & .607 & $-1.000^{* *}$ & $-.999^{* *}$ & 1 \\
\hline & Sig. (2-tailed) & .412 & .646 & .393 & .000 & .001 & \\
\hline
\end{tabular}

**. Correlation is significant at the 0.01 level (2-tailed).

Fig. 4 illustrates the relations among the quality costs and the percentage of each partner from revenue sharing during the four years in the case study.

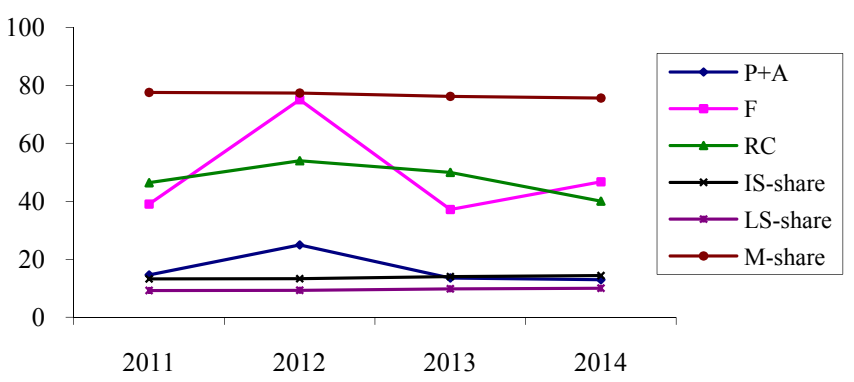

\section{Discussion}

Figure 4. The relations among quality costs and revenue sharing

Ramudhin et al. (2008) focused on total quality cost at suppliers; this study focuses on total quality cost at manufacturer, and infers the other quality costs in the supply chain from the manufacturer accounting books.

From the PAFR model perspective, the following findings are noticed: (1) Recycle cost at manufacturer has a strong positive correlation coefficient with preventive costs. Thus, the preventive cost is increasing as the recycle cost at manufacturer is increasing and vice versa. (2) A strong positive correlation exists between recycle cost at manufacturer and internal failure cost. Thus, the internal failure cost is increasing as the recycle cost at manufacturer is increasing and vice versa. This result indicates that recycle process does not produce standard quality of products. (3) There are negative correlations between recycle cost at supplier and all other quality cost categories. Thus, the quality cost at manufacturer (prevention, appraisal, failure, and recycle costs) decreases as the quality cost at supplier (recycle cost at supplier) increases and vice versa. Further, the stronger negative correlation is between recycle cost at supplier and external failure cost (Correlation coefficient $=-.755, \mathrm{p}>0.05$ ).

As shown in Table 4, a positive correlation exists between prevention and appraisal costs on one hand and internal and external failure costs on the other hand, this finding is align with Abdelsalam \& Gad (2009). In spite of this result is not consistent with the general assumptions of the PAF model, e.g. Ittner (1996), which assumed that an inverse relationship between the prevention and appraisal costs on one hand and the failure costs on the other hand should exist; i.e. when the prevention and appraisal costs increase, the internal and external failure costs are expected to decrease. Similarly, some studies, e.g. Omar \& Murgan (2014), reported that as prevention costs increase, appraisal and failure costs will decrease.

As well, a positive correlation exists between prevention and appraisal cost on one hand, and recycle cost on the 
other hand. Thus, the prevention and appraisal costs increase as the recycle costs increase. This result can be explained logically, where the company maintains its product at an acceptable level of quality, it must spend more costs to prevent pad quality and discover the potential pad quality. Further, there is a positive correlation between failure costs and recycle costs at both manufacturer and suppliers. Therefore, the failure costs increase as the recycle costs increase. This finding implicitly indicates that the recycled components are not in the same quality as the new components; maybe the case study in this paper cannot reach to the acceptable quality of recycled components, or there are other troubles in manufacturing processes. When asking the financial manager of the company, he referred to the political situations during this period that led to many troubles in business activities. The results also show a strong statistically significant relationship between the percentage of revenue sharing for international suppliers and local suppliers. This result ensures all suppliers, either international or local, have attitudes towards the percentage of revenue sharing, i.e. when the percentage of revenue sharing for international suppliers increase, the percentage of revenue sharing for local suppliers are expected to increase and vice versa.

No doubt, there is an inverse relationship between the percentage of revenue sharing for manufacturer and the percentage of revenue sharing for both international and local suppliers, because each partner tries to maximize her/his percentage of total revenue. The results also show that there are weak inverse relationships between quality cost categories and revenue sharing of both suppliers, i.e. whenever the quality cost increases, the percentage of revenue sharing for suppliers decreases. On the other side, there is a weak positive correlation between quality cost and the percentage of revenue sharing for manufacturer, i.e. whenever the quality cost increases, the percentage of revenue sharing for manufacturer increases.

In brief, this study suggests that the revenue sharing proportion allocated to supplier increases as the recycle cost of supplier increases. However, the result does not support this suggestion. We find a very weak correlation between the recycle cost at suppliers and the percentage of revenue sharing of suppliers. As well, the second suggestion in this study is that the revenue-sharing proportion allocated to manufacturer increases as the prevention and appraisal costs increase, as well as the failure costs, the recycle costs of manufacturer, and the recycle costs of suppliers decrease. However, the results are mixed; the revenue sharing proportion allocated to manufacturer has strong positive relation with prevention costs as we suggest, i.e. the revenue sharing proportion allocated to manufacturer increases as the prevention costs increase. Unlike the suggestion in this paper; it has positive relations with internal failure and recycle costs of manufacturer, but not strong. Further, it also has weak positive relations with appraisal and external failure costs. Finally, and align with the suggestion in this paper, the revenue sharing proportion allocated to manufacturer increases as recycle costs of supplier decrease, but this relation is very weak. Table 7 summarizes the important results of this study.

Table 7. Summary of the Results

\begin{tabular}{ll}
\hline $\begin{array}{l}\text { The revenue sharing proportion } \\
\text { allocated to supplier } \boldsymbol{\uparrow} \text { as: }\end{array}$ & - the recycle cost of supplier $\uparrow$ (very weak relation) \\
& - the revenue-sharing proportion allocated to manufacturer $\downarrow$ (very strong \\
& relation) \\
\hline $\begin{array}{l}\text { The revenue-sharing proportion } \\
\text { allocated to manufacturer } \uparrow \text { as: }\end{array}$ & - prevention costs $\uparrow$ (strong relation) \\
& - internal failure $\uparrow$ (not strong relation) \\
& - recycle costs of manufacturer $\uparrow$ (not strong relation) \\
& - appraisal costs $\uparrow$ (weak relation) \\
& - external failure costs $\uparrow$ (weak relation) \\
& - recycle costs of supplier $\downarrow$ (very weak relation)
\end{tabular}

\section{Summary and Conclusions}

This paper discusses new development of quality cost approach, and offers a potential methodology to measure supply chain quality costs, as well as links recycle costs into a common quality cost model.

The author's quality cost model (PAFR) includes prevention, appraisal, failure, and recycle cost. Recycling extracts raw materials from items that might otherwise be considered trash and converts them into new products. Therefore, recycle costs include sorting cost, inspection cost, refurbishing cost and disposal cost that incurred to throw useless components. The PAFR model is used to estimate quality costs in monetary terms. Then, the impact of quality cost on revenue sharing between the partners in the supply chain is examined. 
The impact of implementing quality cost systems on the increasing profit of any organization is obvious [Omar \& Murgan, 2014]. Although many studies examined supply chain and its effects on product cost and quality, to date no research to the best of the author's knowledge in managerial accounting has investigated the quality cost and its effects on the revenue sharing. Revenue sharing can motivate business entities to engage and continue in a supply chain.

This study carries out the quality cost estimation for the year 2011-2014 at filters' company as a part in a supply chain. The main products in this case study include oil filter, fuel filter, air filter, eco filter, and special applications. The results indicated that (1) the preventive cost is increasing as the recycle cost at manufacturer is increasing and vice versa, (2) the internal failure cost is increasing as the recycle cost at manufacturer is increasing and vice versa, (3) the quality cost at manufacturer (prevention, appraisal, failure, and recycle costs) decreases as the quality cost at supplier (recycle cost at supplier) increases and vice versa, (4) surprisingly, a positive correlation exists between prevention and appraisal costs on one hand and internal and external failure costs on the other hand, (5) the prevention and appraisal costs increase as the recycle costs increase, and (6) the failure costs increase as the recycle costs increase.

Under revenue sharing, the following results are found; (1) a very weak correlation between the percentage of revenue sharing of suppliers and the recycle cost at suppliers, and (2) the revenue sharing proportion allocated to manufacturer has strong positive relation with prevention costs, the revenue sharing proportion allocated to manufacturer has positive relations with internal failure and recycle costs of manufacturer, but not strong. Further, it also has weak positive relations with appraisal and external failure costs. Finally, the revenue sharing proportion allocated to manufacturer increases as recycle costs of supplier decrease, but this relation is very weak.

In sum, the results of the case study show that the prevention cost, internal failure cost, and recycle cost at both manufacturer and suppliers play significant roles in the revenue sharing in a supply chain.

This study has a few limitations. It used a case study which focused on a manufacturer to gain insight about the percentage of revenue sharing between partners in a supply chain and the effect of quality costs on revenue sharing, whereas future research could apply this research work on other companies. Although exploratory case study gives deep and robust results, these results cannot be generalized unless more research.

For future research, the relations between quality costs and revenue sharing in many companies and within other type of industries and supply chains are needed to explore. In fact, the present study provides valuable opportunities for future studies, e.g. the effect of reduction in quality costs (include recycle costs) on the asset turnover ratio is needed to examine. Further, this study does not investigate hidden external failure quality costs; future work can examine this issue.

\section{Acknowledgment}

The author would like to thank Damanhour University for support provided on this study. In addition, the author would like to thank the two anonymous referees for comments provided on the paper' earlier drafts.

\section{References}

Abdelsalam, H. M. E., \& Gad, M. M. (2009). Cost of quality in Dubai: An analytical case study of residential construction projects. International Journal of Project Management, 27, 501-511. http://dx.doi.org/10.1016/j.ijproman.2008.07.006

Albright, T. L., \& Roth, H. (June 1992). The measurement of quality cost: an alternative paradigm. Accounting Horizons, 15-27.

Arya, A., \& Mittendorf, B. (2011). Supply Chains and Segment Profitability: How Input Pricing Creates a Latent Cross-Segment Subsidy. The Accounting Review, 86(3), 805-824. http://dx.doi.org/10.2308/accr.00000034

Atkinson, S. E., Stanley, L. R., \& Tschirhart, J. (1988). Revenue sharing as an incentive in an agency problem: an example from the national football league. The RAND Journal of Economics, 19(1), 27-43. http://dx.doi.org/10.2307/2555395

Baiman, S., Fischer, P. E., \& Rajan, M. V. (2000). Information, contracting, and quality costs. Management Science, 46(6), 776-789. http://dx.doi.org/10.1287/mnsc.46.6.776.11939

Balachandran, K. R., \& Radhakrishnan, S. (2005). Quality implications of warranties in supply chain. Management Science, 51(8), 1266-1277. http://dx.doi.org/10.1287/mnsc.1050.0408

Beigl, P., \& Salhofer, S. (2004). Comparison of ecological effects and costs of communal waste management 
systems. Resources, Conservation and Recycling, 41, 83-102. http://dx.doi.org/10.1016/j.resconrec.2003.08.007

Burritt, R., \& Schaltegger, S. (2014). Accounting towards sustainability in production and supply chains. The British Accounting Review, 46, 327-343. http://dx.doi.org/10.1016/j.bar.2014.10.001

Castillo-Villar, K. K., Smith, N. R., \& Simonton, J. L. (2012a). The impact of the cost of quality on serial supply-chain network design. International Journal of Production Research, 50(19), 5544-5566. http://dx.doi.org/10.1080/00207543.2011.649802

Castillo-Villar, K. K., Smith, N. R., \& Simonton, J. L. (2012b). A model for supply chain design considering the cost of quality. Applied Mathematical Modelling, 36, 5920-5935. http://dx.doi.org/10.1016/j.apm.2012.01.046

Chao, C., \& Liao, C. (2011). Approaches to eliminate waste and reduce cost for recycling glass. Waste Management, 31, 2414-2421. http://dx.doi.org/10.1016/j.wasman.2011.07.020

Chao, G. H., Iravani, S. M., \& Savaskan, R. C. (July 2009). Quality Improvement Incentives and Product Recall Cost Sharing Contracts. Management Science, 55(7), 1122-1138. http://dx.doi.org/10.1287/mnsc.1090.1008

Chan, H. K., Wang, X., \& Ruffoni, A. (2014). An integrated approach for green design: life-cycle, fuzzy AHP and environmental management accounting. British Accounting Review, 46(4), 344-360. http://dx.doi.org/10.1016/j.bar.2014.10.004

Corbett, C., \& DeCroix, G. A. (2001). Shared-saving contracts for indirect materials in supply chains: Channel profits and environmental impacts. Management Science, 47(7), 881-893. http://dx.doi.org/10.1287/mnsc.47.7.881.9802

Cruz, N. F., Simões, P., \& Marques, R. C. (December 2012). Economic cost recovery in the recycling of packaging waste: the case of Portugal. Journal of Cleaner Production, 37, 8-18. http://dx.doi.org/10.1016/j.jclepro.2012.05.043

Dacin, M. T., Oliver, C., \& Roy, J. P. (2007). The legitimacy of strategic alliances: An institutional perspective. Strategic Management Journal, 28(2), 169-187. http://dx.doi.org/10.1002/smj.577

Debnath, S., \& Bose, S. K. (2014). Exploring full cost accounting approach to evaluate cost of MSW services in India. Resources, Conservation and Recycling, 83, 87- 95. http://dx.doi.org/10.1016/j.resconrec.2013.12.007

Eisenhardt, K. (1989). Building theories from case study research. Academy of Management Review, 14, 532-550. http://dx.doi.org/10.5465/AMR.1989.4308385

Fayard, D., Lee, L. S., Leitch, R. A., \& Kettinger, W. J. (2012). Effect of internal cost management, information systems integration, and absorptive capacity on inter-organizational cost management in supply chains. Accounting, Organizations and Society, 37, 168-187. http://dx.doi.org/10.1016/j.aos.2012.02.001

GOV.UK, Department for Business Innovation \& Skills. (2013). Future of manufacturing: a new era of opportunity and challenge for the UK - summary report. Available at: https://www.gov.uk/government/publications/future-of-manufacturing.

Govindan, K., \& Popiuc, M. N. (2014). Reverse supply chain coordination by revenue sharing contract: A case for the personal computers industry. European Journal of Operational Research, 233, 326-336. http://dx.doi.org/10.1016/j.ejor.2013.03.023

Groot, J., Bing, X., Bos-Brouwers, H., \& Bloemhof-Ruwaard, J. (2014). A comprehensive waste collection cost model applied to post-consumer plastic packaging waste. Resources, Conservation and Recycling, 85, 79-87. http://dx.doi.org/10.1016/j.resconrec.2013.10.019

Henri, J., Boiral, O., \& Roy, M. (2015). Strategic cost management and performance: The case of environmental costs. The British Accounting Review, 1-14. http://dx.doi.org/10.1016/j.bar.2015.01.001

Henry, A., \& Wernz, C. (2015). A multiscale decision theory analysis for revenue sharing in three-stage supply chains. Annals of Operations Research, 277-300. http://dx.doi.org/10.1007/s10479-014-1735-y

Ireland, R. D., Hitt, M. A., \& Vaidyanath, D. (2002). Alliance management as a source of competitive advantage. Journal of Management, 28(3), 413-446. http://dx.doi.org/10.1177/014920630202800308

Ittner, C. D. (1996). Exploratory evidence on the behavior of quality costs. Operations Research, 44, 114-130. http://dx.doi.org/10.1287/opre.44.1.114

Krishnan, H., \& Winter, R. A. (2011). On the role of revenue-sharing contracts in supply chains. Operations Research Letters, 39, 28-31. http://dx.doi.org/10.1016/j.orl.2010.10.007 
Lakhan, C. (2015). Diversion, but at what cost? The economic challenges of recycling in Ontario. Resources, Conservation and Recycling, 95, 133-142. http://dx.doi.org/10.1016/j.resconrec.2014.12.007

Langfield-Smith, K., \& Smith, D. (2005). Performance measures in supply chains. Australian Accounting Review, 15(1), 39-51. http://dx.doi.org/10.1111/j.1835-2561.2005.tb00250.x

Larsen, A. W., Merrild, H., Moller, J., \& Christensen, T. H. (2010). Waste collection systems for recyclables: an environmental and economic assessment for the municipality of Aarhus (Denmark). Waste Management, 30, 744-754. http://dx.doi.org/10.1016/j.wasman.2009.10.021

Lim, W. S. (2001). Producer-supplier contracts with incomplete information. Management Science, 47(5), 709-715. http://dx.doi.org/10.1287/mnsc.47.5.709.10479

Mamat, S. (January 2012).The Role of Accounting in Supply Chains. Accounting Group, Warwick Business School. The University of Warwick. Available at: http://wrap.warwick.ac.uk.

Omar, M. K., \& Murgan, S. (2014). An improved model for the cost of quality. International Journal of Quality \& Reliability Management, 31(4), 395-418. http://dx.doi.org/10.1108/IJQRM-05-2012-0066

Palsule-Desai, O. D. (2013). Supply chain coordination using revenue-dependent revenue sharing contracts. Omega, 41, 780-796. http://dx.doi.org/10.1016/j.omega.2012.10.001

Parthasarathy, G. (2001). Minimization of cost of recycling in chemical processes. Chemical Engineering Journal, 81, 137-151. http://dx.doi.org/10.1016/S1385-8947(00)00187-X

Ramudhin, A., Alzaman, C., \& Bulgak, A. A. (2008). Incorporating the cost of quality in supply chain design. Journal of Quality in Maintenance Engineering, 14(1), 71-86. http://dx.doi.org/10.1108/13552510810861950

Schiffauerova, A., \& Thomson, V. (2006). A review of research on cost of quality models and best practices. International Journal of Quality and Reliability Management, 23(6-7), 647-669. http://dx.doi.org/10.1108/02656710610672470

Schloetzer, J. D. (2012). Process Integration and Information Sharing in Supply Chains. The Accounting Review, 87(3), 1005-1032. http://dx.doi.org/10.2308/accr-10216

Srivastava, S. (2008). Towards estimating cost of quality in supply chains. Total Quality Management \& Business Excellence, 19(3), 193-208. http://dx.doi.org/10.1080/14783360701600605

Tonjes, D. J., \& Mallikarjun, S. (2013). Cost effectiveness of recycling: A systems model. Waste Management, 33, 2548-2556. http://dx.doi.org/10.1016/j.wasman.2013.06.012

Van der Rhee, B., Van der Veen, J., Venugopal, V., \& Reddy Nalla, V. (2010). A New Revenue Sharing Mechanism for Coordinating Multi-echelon Supply Chains. Operations Research Letters, 38, 296-301. http://dx.doi.org/10.1016/j.orl.2010.03.004

Vann, C. E. (March/April 2016). Strategic Benefits of Integrating the Managerial Accounting Function with Supply Chain Management. The Journal of Corporate Accounting \& Finance, 21- 30. http://dx.doi.org/10.1002/jcaf.22138

Wang, J., \& Shin, H. (January 2015). The Impact of Contracts and Competition on Upstream Innovation in a Supply Chain. Production and Operations Management, 24(1), 134-146. http://dx.doi.org/10.1111/poms.12218

Yin, R. (1994). Case Study Research: Design and Methods. Second Edition. Sage, London.

Zhang, J., Liu, G., Zhang, Q., \& Bai, Z. (2015). Coordinating a supply chain for deteriorating items with a revenue sharing and cooperative investment contract. Omega, 56, 37-49. http://dx.doi.org/10.1016/j.omega.2015.03.004

Zhu, K., Zang, R. Q., \& Tsung, F. (March 2007). Pushing quality Improvement along supply chains. Management Science, 53(3), 421-436. http://dx.doi.org/10.1287/mnsc.1060.0634

Zimwara, D., Mugwagwa, L., Maringa, D., Mnkandla, A., Mugwagwa, L., \& Ngwarati, T. (January 2013). Cost of Quality as a Driver for Continuous Improvement - Case Study - Company X. International Journal of Innovative Technology and Exploring Engineering (IJITEE), 2(2), 2278-3075. 